ISSN 2411-4758 (Print) 2518-1602 (Online)

Native word in ethnocultural dimension, Drohobych, Posvit, 2021, pp. 141-151.

DOI: https://doi.org/10.24919/2411-4758.2021.214063

УДК 811.163.1:811.161.2’42:271.4(477)-722

\title{
ХУДОЖНЯ ТВОРЧІСТЬ О. КИРИЛА СЕЛЕЦЬКОГО В КОНТЕКСТІ ДУХОВНО-ПРОСВІТНИЦЬКИХ ТА ЕСТЕТИЧНИХ ПОШУКІВ І МОВНО-МЕНТАЛЬНИХ ВИКЛИКІВ
}

\author{
Марія СТЕЦИК, \\ кандидат філологічних наук, доцент кафедри украӥнської мови, \\ Дрогобицький державний педагогічний університет імені Івана \\ Франка (Україна, Дрогобич) stetsykmariast@gmail.com
}

ORCID: http://orcid.org/0000-0001-7161-0621

Research ID: AAD-4393-2019 http://www.researcherid.com/rid/AAD-4393-2019

Статтю подано до редколегіï/The article is submitted to the editorial board:

12.10.2020.

Статтю опубліковано/The article is published: 22.02.2021.

Статтю присвячено мовотворчості Кирила Селецького - священника української греко-католицької иеркви, письменника, громадського діяча, просвітника. Зазначено, щуо його художні твори слугують ілюстрацією для розуміння складного й суперечливого прочесу становлення украӥнської літературної мови в Галичині та органічної взаємодії живої мовної стихії і церковнослов'яні на всіх рівнях. Наголошено, щуо в художніх дискурсах К. Селецького иерковнослов'янська мова стає вагомою стилетвірною категорією й органічно вплітається в говіркову текстову канву. Більшість художніх текстів у своїи основі залишаються українськими й не створюють жодних бар 'єрів у прочесі рецепції, позаяк зберігають чітко артикульовану украӥнськомовну основу. Автор статті доходить висновку, щчо церковнослов'янська мова-стиль відігравала в прочесі становлення сучасної украӥнської літературної мови особливу роль - роль ї духовного варіанта.

Ключові слова: мовотворчість; говірка; варіантність; ідіостиль; церковнослов 'янська мова; текст; експресія; сакральне.

\section{ARTISTIC CREATIVITY OF FATHER KYRYLO SELETSKYI IN THE CONTEXT OF SPIRITUAL-EDUCATIONAL AND AESTHETIC SEARCHES AND LINGUO-MENTAL CHALLENGES}

\author{
Mariia STETSYK, \\ Candidate of Philological Sciences, Associate Professor of the Department \\ of Ukrainian Language, Ivan Franko Drohobych State Pedagogical \\ University (Ukraine, Drohobych) stetsykmariast@gmail.com
}


The article is devoted to the language creation of Father Kyrylo Seletskyi - a clergyman of the Ukrainian Greek Catholic Church, founder of two monastic congregations, an advocate of the spiritual and national Order in Galicia, a sower of "healthy grain for our people", a stalwart supporter of the Ukrainian word.

$K$. Seletskyi's literary works serve as an excellent illustration for understanding a complex and often contradictory process of the Ukrainian literary language formation in Galicia, an insight into a folk polyphony of dialectal words of that epoch, dialectical interaction of the living language and Church Slavonic at all levels. Not only does the dialectal variability of many lexemes give a colorful expression to the characters'speech, but also illustrates the evolutionary stages of development of the Transnistrian branch of the Ukrainian language.

The author emphasizes that in K. Seletskyi's artistic discourses, the Church Slavonic language as a historically and culturally important segment of the Ukrainian language becomes a special text-and style-building category, organically intertwines with its living canvas. Numerous Church Slavonicisms explicate the semantic specificity of the text and its general sacral-didactic intention through grammatical, lexical and phonetical adaptation to dialectal speech.

Literary theological-educational, informative-moralizing texts are full of religious vocabulary, which gives the impression of a spiritual cliché, yet they (the texts) remain inherently Ukrainian and do not create any barriers in the process of perception, as they retain a clearly articulated Ukrainian-language basis.

The author concludes that the Church Slavonic language-style played a special role in the process of the modern Ukrainian literary language formation - the role of its spiritual variant.

Key words: language creation; dialect variability; idiosyncrasy; Church Slavonic language; text; expression; sacred.

Постановка проблеми. Ім'я Кирила Селецького - душпастиря української греко-католицької церкви, засновника двох монаших згромаджень, письменника, просвітника, сподвижника національної справи, зрештою, непересічної особистості - останнім часом знане не лише у вузькому конфесійному середовищі, а й упізнаване серед достатньо широкого загалу. За визначенням І. Розлуцького, «постать о. Кирила Селецького - велична й феноменальна на обширах української духовності і культури» (Розлуцький, 2018, с.15). Скромний парох для багатомільйонної української громади (поза конфесійною належністю!) став взірцем духового Чину, «сіячем здорового зерна», що, як і будитель Маркіян Шашкевич, «підносив чашу Рідної Землі під Господа святе благословення» (Л. Полтава).

К. Селецькому, окрім постійної духовної опіки, вельми залежало на тому, аби українці повірили в себе, були самодостатніми, позбувалися вікових ментальних комплексів (меншовартості, упослідженості, по- 
кірливості), завдяки двом чинникам - ревній молитві рідною мовою i праці - навіть із найнижчих прошарків піднімалися на суспільний п’єдестал. «О. Селецький, - зауважує I. Розлуцький, - вірить в силу людського духа, він вірить в людину, яка з Божою допомогою здатна змінити долю всієї країни» (Розлуцький, 2018, с. 37). Перебуваючи на парохії в Мількові, душпастир 1868 року для простих людей видає читанку «Своя хата» («сельському народу на хосен»). За епіграф бере вже на той час крилаті Шевченкові рядки - «В своїй хаті своя правда, і сила, і воля». В унісон звучить і прикінцева строфа поезії душпастиря, якою відкривається читанка: Тому, мої милесенькі, не лишайте хати, / где вас мати згодувала, / Виплекала мати (Селецький, 2018, с. 45).

На жаль, творчість о. Кирила Селецького довший час була відома лише вузькому колу фахівців (богословам, історикам). 2018 року вийшов I том ювілейного та найповнішого на сьогодні видання творів, у якому зібрано його праці - художні твори різних жанрів, теологічно-просвітницькі виклади, пізнавально-публіцистичні нариси, розлогі оповідки 3 життя відомих світських і духовних осіб, що засвідчують універсальність таланту душпастиря та його неоціненний внесок в національну духовно-просвітницьку та мовну скарбницю. Це зумовило вибір теми наукової студії та її новизну.

Аналіз досліджень. Бібліографія творчості К. Селецького вельми скромна. Найбільш повно життєвий шлях (спорадично - творчість) висвітлив Т. Вергун й оприлюднив у Науковому тримісячнику «Богословія» (Вергун, 1988). Питання богослов'я та облаштування чернечого життя, експліковані в працях душпастиря, заторкує у своїх публікаціях Стефанія Марко. Перший системний огляд художньої й - частково - публіцистичної творчості о. Кирила представив I. Розлуцький у розлогій передмові до I тому Вибраних творів, обравши за назву трансформовані рядки душпастиря - «Сіяч здорового зерна для свойого люду» (Розлуцький, 2018, с. 15-40). Дослідник намагається окреслити тематичні обрії прози, проаналізувати іiі ідейно-художні особливості, вписати в тогочасний вітчизняний та європейський літературний контекст. Зауважує I. Розлуцький і наскрізну духовно-християнську вісь творчості Кирила Селецького. Прикметно, що зазначені особливості науковець розглядає не лише на прикладі літературних текстів, а й досить вичерпно аналізує християнську публіцистику К. Селецького. Артикулює дослідник і важливість мовного питання та акцентує на проблемі ідентичності людини крізь призму рідної церкви та материнського слова. До речі, Кирило Селецький пов'язував національно-мовне й духовне відступництво 3 духовною темрявою та моральним занепадом особи й суспільства. Част- 
ково питання творчості о. Кирила Сятецького заторкувалися у викладах доповідачів ювілейної конференції, що відбулася 19-20 вересня 2018 року (Львів, Греко-католицька духовна семінарія Святого Духа).

Маємо на меті висвітлити домінантні риси мовостилю художніх текстів о. Кирила Селецького з урахуванням духовних напрямних його творчості та історичних, мовних і конфесійних умов та викликів доби. Для нас важливо також окреслити роль і місце о. Кирила в національно-духовному та просвітницькому поступі діячів греко-католицької церкви, які часто брали на себе місію формування самосвідомості й самототожності народу в умовах його бездержавності та суспільних i ментальних утисків.

Виклад основного матеріалу. К. Селецькому випало творити в складних і суперечливих історико-політичних реаліях. Передовсім імпонує мовна концепція, якої дотримувався письменник: у тодішніх умовах, коли в Галичині не було більш-менш прийнятної правописної системи, коли відчувалося у всьому агресивне москофільство й не надто прихильне полонофільство, - о. Кирилу вдалося віднайти (випрацювати, витворити) свою питому мовноговіркову матрицю, актуалізувати духовно-просвітницький та націєвиховний наратив. Різноформатні - богословські, художні, публіцистичні - твори Кирила Селецького виходили в різних містах (Перемишль, Львів, Жовква, Коломия). Природно, що тексти зазнавали не лише редакторських - цілком закономірних - втручань, а й - більшою чи меншою мірою - несли на собі відбиток і певних лінгвальних уподобань, видавничих традицій, рівно ж і чинників суб'єктивного характеру. Маємо на увазі горезвісне «язичіє» (на зміну старим москофілам прийшли зухвалі молоді), яке в другій половині XIX століття в Галичині мало ще досить сильні позиції. Опоненти народної української мови, зосібна Д. Зубрицький, щедро засипані «миколайчиками» та густо обкурені димом з московських кадильниць, «на користь і в догоду» своїм ідейним та ідеологічним покровителям називали їі живу народну мову - «язиком черни, пастухов, пасечников, Грицьков».

Не можемо не звернути увагу й на те, що творчість К. Селецького припадає на той час, коли лише накреслювалися лінгвістичні підходи до мови на противагу загальнофілологічним. Свою роль відігравали й інші - історичні та політичні - чинники. Як образно сказав про це Є. Щурат, над Галичиною сходило сонце, але не зійшло (Огієнко, 1995, c. 178). «Весна народів» (1848 р.) не стала початком мовного відродження та мовної консолідації. Уже з 1849 року розпочалися запеклі (іншими словами тут і не скажеш) суперечки про мову та правопис. На превеликий жаль, направду доленосні й націєконсолідаційні ідеї Маркіяна 
Шашкевича розчинилися в новому москофільському багні. Навіть сподвижник Шашкевича Яків Головацький чи не найбільше спричинився до «правдивого дивогляду», за визначенням I. Огієнка, в нашій історії. К. Студинський цілком слушно зазначає, що ця мова не була ані російською, ані українською, ані церковнослов' янською, а якоюсь строкатою мішаниною всіх трьох з незначним додаванням народної мови. I цим «дивоглядним» язичієм навчали рідної мови в гімназіях Галичини. В одній із них - Самбірській - навчався й Кирило Селецький. Він, на щастя, закінчив гімназію раніше, аніж розпочалися всі оці мовні експерименти, більше зазнав утисків з боку шовіністично налаштованих польських викладачів та гімназистів і почувався не вельми комфортно через тодішній латино-німецький освітній простір. До слова, коли в Самбірській гімназії (а це середина 60-х років XIX ст.) почали вести виклади української мови, то знайшлися навіть такі учителі рідної словесності, які, якби на це дали добро, заборонили б іiі, а українську літературу звели б... до Пушкіна і Ломоносова (Див. про це: Огієнко, 1995, с. 179). Усе це відбувалося в умовах лояльного ставлення австрійського уряду до галичан та певного сприяння в задоволенні їхніх освітньо-культурних і духовних потреб. Направду сталося так, як сумовито резонував Т. Шевченко: «Не так тї воріженьки, як добрії люде...».

У тодішній Галичині, за сучасними визначеннями, повним ходом ішла одна з форм гібридної війни, яка не зводилася, як це на перший погляд видається, до азбучної, а була справжнім мовно-ідеологічним протистоянням, заторкувала основи національного буття, національної самоідентифікації, розривала ментальну тяглість, спадкоємність, що головно втілюється в мові. Звісно, могутнім древом над брудним потоком загумінкових мовних баталій, дріб'язкових сутичок за йор, єр і за апостроф (і це в той час, коли вже були витворені високі зразки і літературної мови, і фонетичного правопису в наддніпрянській Україні) стала мовна практика та мовотворчість Івана Франка - як органічна наддністрянська гілка соборної української мови. І цю живу гілку ревно плекав ще перед Каменярем скромний душпастир Селецький.

Свіжістю, органічністю, живим подихом колоритного народного мовлення віє від багатьох його художніх текстів. Слушно вважають, що повноправне громадянство діалектові в українській літературі надав В. Стефаник. Стефаникове говіркове мовомислення як неповторний художній феномен завжди перебувало на вістрі дослідницької уваги, митця називали «абсолютним паном форми», «мужицьким Бетховеном». Але задовго до Стефаника, занурившись чутливим душпастирським серцем у «біополе галицького села», ліпив свого героя його природним сло- 
вом, може, не так «коротко, сильно і страшно», як визнаний класик, але щиро, зворушливо, проникливо, зчаста сентиментально-романтично, іноді - 3 м'яким світлим гумором, подекуди 3 витонченою іронією, і ревний ісповідник народної мови К. Селецький:

Над берегом широкого Дністра розкинене меж вербами сельце невеличке. Нарід там мешкає заможний, хати всюда статні, а коло хат стожків та оборогів з сіном $і$ з збіжом повно. Помеже хатами єдна тілько якось для ока принаднійиа, білов глинков вимускана, - над нев горує розсохатий дуб, а на том дубі бузьок гніздо си увив. Коло той хати харність повсюду велика, сад ю окружає докола, а в том саді яблок $i$ грушок без ліку. За садом пасіка невеличка (Селецький, 2018, с. 51).

Яка гарна, яка добірна й максимально наближена до літературної мова! А те вишукане тло як доречно помережане говірковими вкрапленнями - фонетичними, граматичними, лексичними. I жодне слово-меж, си, сельце, стожки, глинков, збіжє, горує, бузьок-не порушує дивовижної мовної гармонії, не дисонує, не справляє враження чужорідного тіла. Щоб словами ось так візуалізувати майже ідеальний (і заможний!) український світ з його ошатною білою хаткою, садком - не конче вишневим, вербами як неодмінним атрибутом рідного краєвиду, лелеками (як у Тараса Шевченка, Марка Вовчка чи I. Нечуя Левицького), - потрібен неабиякий письменницький хист та особливий - глибинно й питомо - український стан душі. Тут кожне слово постає як концептуальний поетизм чи - радше - згорнутий концепт народного, без фальшивих етнографічних спецефектів, світовідчуття. Зайве говорити тут і про неперевершений ритм прози - як поважний плин Дністра, що виривається 3 карпатських жбирів на рівнинну просторінь.

Не можемо сказати, що всі художні твори о. Кирила однаково досконалі в мистецькому плані, але добротність, фактурність, мовна збалансованість й оригінальна образність незаперечні. Особливу роль тут відіграє говіркове мовлення, майстерні діалектні вкраплення в текст або ж цілі масиви:

Нужда ж то била велика, коли, мов чорна туча, надтягнули горди поганой татарви. Люденькове одбігали всьо, хату і газдівство, утікали в далекі ліси, аби не попастися в руки лихого ворога, где їх чекала смерть або тяженькая неволя (Селецький, 2018, с. 47); Наввірилася вже мужови тая неустанна посварка. Схопився з постелі, пішов до стодоли,скенув околот на бойще, заніс під шопу, тамка го розв'язав $i$ вернувся до хати;велить старому з п'єца злізти і жене на обору (Селецький, 2018, с. 63). 
Перед сучасним читачем і дослідником-філологом постає багатющий органічний діалектний пласт (бойківсько-наддністрянська говірка), який уже частково занесено до Червоної книги мови. Чимало колоритних слів і словоформ потребують відповідного коментаря. Це і хосен, харність, ключатися, нехибно, боїско, бачно, добичата, вимусканий, пересада, під, потрава, обора, омаста, зело, услів'є, таний, доткливий, старунок, стяж, часосказ, иибатися, глядати, грімкий. Для галичанина - сучасника Селецького - це був активний словниковий фонд, зрештою, як і більшість фонетичних і граматичних діалектизмів, що вписувалися в систему тогочасної літературної мови.

Художні тексти о. К. Селецького слугують також чудовою ілюстрацією для розуміння складного й часто суперечливого процесу становлення української літературної мови в Галичині, для пізнання тогочасної народної поліфонії говіркових слів, діалектичної взаємодії живої мовної стихії та церковнослов'яні на всіх мовних рівнях - фонетичному, дериваційному, морфологічному: люди $і$ люде, житя $i$ житє, чоловік $i$ человік, дітина і дитина, вдоволенє, вдоволеніє $і$ вдоволеня, покаяня $i$ покаянє, ще і єще, розгрішенє і розріменє, патріарх і патріарха, архімандрит і архімандрита, оден, один і єден, був і бив, покидає і покидат, mу і тут, мож і можна, треба і тра. Діалектні фонетичні особливості багатьох слів виступають не лише яскравими ідентифікаторами мовних партій персонажів, а й ілюструють еволюційні етапи розвитку мови: жерело, зеркало, звін (і дзвін), желізо, скрань, скіра, вельблюд, воробці, пчола, желізниця.

Декілька століть у розмовній та писемній практиці - у церковній проповіді, в деяких місцевих перекладах Свангелія, в літописах - вільно й широко доповнювали себе два джерела: українська мова (розмовна і книжна) та церковнослов'янська мова як їі духовний стиль. У храмах української греко-католицької церкви збереглася й донині українізована вимова церковнослов'янських богослужбових текстів. Саме київський ізвод був наближений складом лексики, наголосами, вимовою, граматичними особливостями до староукраїнської (української) мови. Чи не тому Петро I заборонив друкувати церковні книги київським ізводом, а дозволяв лише московським.

Духовні тексти, пристосовуючись до місцевої мови, обов'язково зберігали класичні особливості високого стилю. Напевно, саме таку традицію запровадили для своїх численних учнів ще солунські брати: не можна мову Святого Письма і тексти, що творилися на його основі або перебували в силовому полі святого, священного, змішувати з побутовими, буденними, а то й розважальними поняттями. Цієї мовної рівноваги, 
цього стильового балансу майстерно дотримано в текстах К. Селецького, вишукано інкрустованих самоцвітами високого стилю.

Відомо, що українські діячі XVII - XVIII століть у різних галузях церковного й навколо- чи навіть позацерковного життя користувалися церковнослов'янськими текстами та окремими мовними елементами як специфічним стилем староукраїнської мови поруч із звичною народною, або, як іï називали, простою руською. Видатні мовознавці кінця XIX початку XX століття були близькі саме до такого тлумачення феномену церковнослов'янської мови. Образно кажучи, церковнослов'янська мова як органічний сегмент української мови виконувала функції їі духовного варіанту: граматично, лексично та фонетично пристосовуючись до живої народної мови, вона зберігала змістові (смислові, концептуально-сенсові) етико-естетичні особливості, сакральні (біблійно-християнські) первні та надавала усним і писемним текстам неповторного ореолу - піднесеності, урочистості, величності. В історії становлення української мови (особливо в XIX ст.) саме церковнослов'янський мовний фермент укріпив іiі питомий духовний фундамент, зберіг багатовікову тяглість священно-духовного компонента (див. про це: Майданович, 2000, с. 330 - 333). Зрештою, яскравим свідченням є поезія Тараса Шевченка - патріотична, філософська, духовна. Синтез народнопісенного, розмовно-побутового й сакрального найповніше втілено в його знаменитій поемі «Марія». Аналогічні текстові масиви подибуємо й у К. Селецького, особливо колоритно представлено їх в оповідках народно-християнського спрямування («Жертва любови», «Ікона Божої Матері»).

- Придивися близше тій іконі! Ось меч, щзо ним прободена грудь єї... се знам'я той превеликой болізни, котра після предсказаня Симеона прошибла єї душу, коли бачила свого сина на кресті, межи двома розбійниками розп'ятого. Обильні слези текут з Сї очей, котрі разом зі зложеними руками до неба возносить... се доказ, щуо здалася на волю Божу і уповає на Господа Бога. Золоті лучі, окружаючі Сї голову, знаменують, щзо Вона зістала прославлена в небі, чого доступила тим, щуо терпеливо перенесла всяку болізнь $і$ во всім згодилася з Божою волею... Не перечу, щуо ти понесла превелику страту, бо муж і дитина политили тебе; подвійний меч болізни прочибнув душу твою. Але зверни твої очи і серие твоє до неба, здайся на волю Божу, уповай на Господа Бога, жертвуй Сму твою болізнь і проси, щуоби потішив тебе і наділив силою звисше. Тая сама віра, з котрою відповіла Пречистая Діва на привіт ангельський: "Се я раба Господня, да будет мні по глаголу твоєму!» - одушевляла єї також в годині найтяжшої болізни. Тям собі, щзо як 
золото в огни чиститься $і$ набирає природного блеску, так і наша душа в переминаючих терпінях очищаєся, $i$ усовершає, $i$ стає достойною статися участницею вічної слави. Сам Христос мусів дорогою терпіня увійти до вічної слави. Тою дорогою поступали Пречистая Діва Марія i прочі Божі угодники. А вже ж і для нас нема якої-то другої дороги до неба...(с. 81)

У цьому уривку простежуємо, як Кирило Селецький майстерно вибудовує свій мовний собор, де гармонійно поєднується народно-розмовний каркас зі стилістично маркованими та конотованими словами-конфесіоналізмами, серед яких лексичні й словотвірні старослов'янізми, грецизми (знам'я, глагол, болізнь, обильний, предсказаня возносити, уповати, благодаренє, знаменя, жертва, жертвувати, усовершати, ікона, терпінє, небо, сохраняти, жизнь безконечная), теоніми й бібліоніми (Діва Марія, Матенька (Матінка) Христова, Пречиста Діва, Мати Божа, Божі угодники, Господь Бог, Симеон), які несуть на собі відчутний вплив фольклорної традиції. Попри насиченість багатьох текстів відповідно маркованою лексикою, яка справляє враження своєрідного духовного кліше, він (текст) у своїй основі залишається українським і не створює жодних бар'єрів у процесі його рецепції. Прикметно, що не лише художні тексти, а й богословсько-просвітницькі, повчально-моралізаторські та навчально-християнські зберігають саме українську мовну основу. У наведеному фрагменті бачимо, як українська церковнослов'янь (не штучне язичіє) стає особливою тексто- і стилетвірною категорією, не руйнуючи живої канви народної мови. Це слугує для підтвердження того, що церковнослов'янська мова-стиль відігравала у процесі становлення сучасної української літературної мови аж ніяк не другорядну роль і її місце у величній споруді соборної української мови, звісно ж, не на маргінесі!

На жаль, знищення української державності й культури почалося зі знищення духовного стилю староукраїнської мови, передовсім із вилучення їі корінних (питомих) церковнослов'янських елементів.

Висновки. Отець Кирило Селецький - архискромний і ревний (аж до самозречення) трудівник на українській духовній і мовно-просвітницькій ниві, мабуть, не надто переймався тим, як його творча спадщина резонуватиме через роки й століття. Він у ті складні часи робив на славу Божу те, до чого стреміла його щира й небайдужа душа, чого прагнуло серце духовного батька, який чувся до обов'язку перед увіреними йому дітьми - бідним, притлумленим, але таким спраглим повноцінного буття у власній хаті, ревної молитви рідною мовою у своїй церкві галицьким людом. Талановите й проникливе слово отця Кирила, 
питомо народне, живе, колоритне, пройшовши крізь горнило іншого Слова, освяченого горніми сферами, - Слова Божого, одкровення Духу, лягало твердим і надійним каменем (не хочемо гіперболізувати, тому не кажемо наріжним, зрештою, цього не хотів би і сам простий душпастир) у підмурівок величного собору української мови - цієї святая святих повноцінного національного буття.

У перспективі маємо на меті провести більш системні студії над мовостилем К. Селецького (комплексні й різнорівневі). Заслуговує на увагу колоритний фраземікон, що немовби вихоплений із живомовної стихії; каскади емотивно-експресивної лексики, які увиразнюють дотепне й органічне діалогове мовлення та гармонійно доповнюють характеристики персонажів, майстерно виліплені їхнім питомим словом. Більш грунтовного викладу потребує й проблема функційного наповнення численних церковнослов'янських вкраплень як інтенсифікаторів авторського духовно-просвітницького наративу.

\section{СПИСОК ДЖЕРЕЛ}

Селецький, Кирило (2018). Вибрані твори: У 2-х т. Т. 1. [упоряд. та ред. Ігор Розлуцький, I, с. Маркіяна (Василишин)]. Дрогобич : Коло.

\section{СПИСОК ЛІТЕРАТУРИ}

Біленька-Свистович, Л. \& Рибак, Н. (2000). Церковнослов'янська мова : Підруч. зі словником для духов. навч. закл. Київ : Криниця.

Вергун, Теодор. (1988). О. Кирило Селецький. Богословія : Науковий тримісячник, № 52. Рим.

Майданович, Тетяна (2000). Духовний стиль української мови. Л. Біленька-Свистович \& Н. Рибак. Церковнослов'янська мова : Підруч. зі словником для духов. навч. закл. Київ : Криниця, $325-334$.

Марко, Стефанія (2018). Отець Кирило Селецький - засновник перших активних чернечих Згромаджень в УГКЦ. Наукові записки УКУ. Серія : Богослов'я. Випуск 5, $116-117$.

Огієнко, І. І. (Митрополит Іларіон) (1995). Історія української літературної мови. Київ : Либідь.

Розлуцький, I. (2018). Сіяч здорового зерна для свойого люду. Кирило Сeлецьький. Вибрані твори: У 2-х т. Т. 1. Дрогобич : Коло, $15-40$.

\section{REFERENCES}

Bilenka-Svystovych, L. \& Rybak, N. (2000). Tserkovnoslovyanska mova : Pidruch. zi slovnykom dlya dukhov. navch. zakl [Church Slavonic: Textbook. with a dictionary for theological schools] Kyiv : Krynytsya. [in Ukrainian]

Verhun, Teodor. (1988). O. Kyrylo Seletskyy. Bohosloviya [O. Kyrylo Seletsky. Theology]. Naukovyy trymisyachnyk - Scientific Quarterly, № 52. Rome. [in Ukrainian] 
Maydanovych, Tetyana (2000). Dukhovnyy styl ukrayinskoyi movy [Spiritual style of the Ukrainian]. L. Bilenka-Svystovych \& N. Rybak. Tserkovnoslovyanska mova : Pidruch. zi slovnykom dlya dukhov. navch. zakl [Bilenka-Svistovich, L. \& Rybak, N. (2000). Church Slavonic: Textbook. with a dictionary for theological schools]. Kyiv : Krynytsya, 325 - 334. [in Ukrainian]

Marko, Stefaniya (2018). Otets Kyrylo Seletskyy - zasnovnyk pershykh aktyvnykh chernechykh Z·hromadzhen v UHKTS [Father Kyrylo Seletsky was the founder of the first active monastic congregations in the UGCC]. Naukovi zapysky UKU. Seriya : Bohoslovia. - UCU scientific notes. Series: Theology. Issue 5. Pp. 116-117. [in Ukrainian]

Ohiyenko, I. I. (Mytropolyt Ilarion) (1995). Istoriya ukrayinskoyi literaturnoyi movy [History of the Ukrainian literary language]. Kyiv : Lybid. [in Ukrainian]

Rozlutskyy, I. (2018). Siyach zdorovoho zerna dlya svoyoho lyudu [A sower of healthy grain for your people]. Kyrylo Seletskyy. Vybrani tvory: U 2-kh t. T. 1 [Kirill Seletsky. Selected works: In 2 volumes.]. Drohobych : Kolo, 15 - 40. [in Ukrainian] 